\title{
Potret Kinerja Polri dalam Bingkai Media \\ Analisis Kinerja Polri Menurut Rekam Data Media Massa 2014- 2015
}

\author{
Muhammad Muntasir \\ Peneliti di Freedom Foundation Jakarta dan pengajar Universitas Pelita Nusantara, Bekasi
}

\section{Abstract}

This article explains that, although during 2014 the National Police played a major role in securing a series of electoral processes, there were still many media coverage exposure that contained negative sentiments about the performance of the other National Police that influenced people's perceptions and attitudes towards the National Police. Furthermore, during the 2015 quarter, the Police did not seem to be able / able to significantly take care measures to suppress the negative sentiment while increasing positive sentiment.

\author{
Keywords \\ Polri; masyarakat; hukum reformas; \\ pelayanan

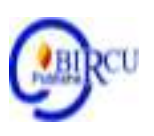

\section{Pendahuluan}

Sesuai kutipan di atas, Kepolisian Republik Indonesia (Polri) dalam perannya sebagai salah satu institusi penegak hukum akan selalu menghadapi tantangan, baik tantangan berat maupun ringan dalam tugasnya. Tantangan tugas Polri bukan saja pada level institusi pusat maupun wilayah, individu anggota perwira berpangkat tinggi, menengah, maupun anggota berpangkat rendah,namun juga terjadi di tingkat lapangan saat di mana anggota Polri berhadapan langsung sebagai pelayan dan pelindung masyarakat.

Polisi dan masyarakat merupakan dua elemen yang saling membutuhkan, sebab polisi lahir dan berasal dari masyarakat. Sementara di sisi lain, masyarakat dibutuhkan polisi karena di sanalah ladang pekerjaannya. ${ }^{1}$

Harapan masyarakat tentang polisi dalam melaksanakan tugasnya sangat di nantikan oleh publik, oleh sebab itu, polisi juga harus memperhatikan kinerjanya yang dari hari kehari, apakah yang mereka lakukan sudah memenuhi harapan masyarakat. Masyarakat merupakan tempat lahan yang sangat potensial bagi polisi untuk mengabdi, dan ini merupakan suatu amanah atau tongkat estafet yang di tinggalkan oleh para pejuang- pejuang zaman dahulu. Maka seharusnyalah sebagai polisi harus menjadi yang terbaik di antara para penegak hukum yang ada di negeri yang kita cintai ini. Di banding dengan penegak hukum yang lain, tugas polisi sangatlah berat dan membutuhkan dukungan dari berbagai pihak. Anton Tabah dan Satjipto Raharjo dalam buku "Polisi pelaku dan Pemikir" mengatakan bahwa prestasi kerja polisi merupakan fungsi dari keadaan sekelilingnya. Ini menunjukkan bahwa ada suatu ikatan yang erat antara tugas polisi dengan lingkungan, masyarakat dan bangsanya. ${ }^{2}$

\footnotetext{
${ }^{1}$ Baca, Adrianus Meliala, Memulai Lagi Reformasi Kepolisian, Kompas, 23 Juni 2015.Tulisan ini merupakan analisis atas data koleksi Prof. Adrianus E. Meliala.

${ }^{2}$ Satjipto Raharjo dan Anton Tabah. Polisi, Pelaku dan Pemikir, Jakarta: Gramedia Pustaka Utama,1993, hal 24.
} 


\section{Muhammad Muntasir: Potret Kinerja Polri dalam Bingkai Media Analisis Kinerja Polri Menurut Rekam Data Media Massa 2014-2015}

https://siasatjournal.com/index.php/siasat

Di sinilah bukti profesionalisme Polri selalu diuji. Harsya W Bactiar, salah seorang pakar ilmu kepolisian pernah menyatakan, hanya sebagian kecil personil Polri yang berfikir dan bertindak profesional. Menghadapi masalah seperti ini, menurut Bachtiar, peningkatan kualitas akademis melalui pendidikan Pasca Sarjana Ilmu Kepolisian merupakan keharusan. ${ }^{3}$ Penulis dalam hal ini sependapat dengan Harsya W Bachtiar, untuk meningkatkan keprofesional polisi tidak cukup dengan pendidikan SLTA untuk bintara, mereka harus memperoleh pendidikan yang lebih baik, alangkah baiknya mereka mendapat pendidikan di perguruan tinggi paling tidak tingkat diploma untuk menambah wawasan berfikir mereka dalam aktifitas sehari-hari.Untuk mengukur profesionalisme, menurut Sullivan, pakar ilmu kepolisian kriminilog AS, dapat dilihat dari tiga parameter, yaitu motifasi, pendidikan, dan penghasilan. Agar mempe- roleh aparat penegak hukum (inklusif polisi) yang baik, haruslah dipenuhi prinsip Well MES, yaitu well motivation (motivasi bagus), Well education (pendidikan baik), dan well salary (gaji layak). ${ }^{4}$

Penulis sangat setuju dan sependapat dengan apa yang di kemukakan oleh Sullivan, bahwa ketiga hal tersebut supaya diperhatikan dengan serius oleh pihak pemerintah dan Polri khususnya.

\section{Kajian Pustaka}

\section{Peran Media}

Media massa di zaman modern ini berperan sangat signifikan dalam hubungan antara polisi dan masyarakat. Tanpa media massa hubungan antara polisi dengan masyarakat tidak akan efektif. Sorotan terhadap Polri yang faktual baru-baru ini adalah sekuel drama "perseteruan"dengan Komisi Pemberantasan Korupsi (KPK) yang diawalidengan penetapan calon Kapolri Komjen Budi Gunawan sebagai tersangka oleh KPK. Meskipun pada akhirnya Presiden Joko Widodo telah melantik Kapolri definitif yaitu Jenderal Polisi Badrodin Haiti, ${ }^{5}$ namun rangkaian drama yang terkait dengan kasus tersebut sepertinya belum sepenuhnya tamat dengan dipanggilnya penyidik KPK Novel Baswedan oleh Bareskrim Mabes Polri atas kasus lama yang melibatkan namanya. Rangkaian kejadian tersebut merupakan contoh kasus yang mencuat menjadi public issuekarena terjadi di tingkat pusat pada level pimpinan Polri sehingga memuat energi potensial yang besar dan dapat menggerus kinerja Polri secara keseluruhan apabila tidak segera diselesaikan.Kita berharap semua pihak yaitu KPK, Pemerintah, dan terutama internal Polri sendiri segera menyadari akan potensi kerugian yang mungkin akan timbul apabila persoalan tersebut masih berlarut-larut tak kunjung usai.

Terlepas dari kasus itu, terdapat beberapa persoalan yang menjadikan potret Polri secara umum masih terlihat buram di mata masyarakat maupun madia massa yang semestinya menjadi perhatian serius untuk dapat segera dibenahi. Hal tersebut dilakukan guna menanggapi dan menjawab sentimen negatif yang muncul dan masih melekat di tubuh Polri sampai saat ini. Menurut catatan data yang terekam, baik oleh media massa maupun National Police Commission of Indonesia atau Kompolnas (Komisi Kepolisian Nasional), terdapat beberapa PR yang harus segera diselesaikan menyangkut urusan internal lembaga Polri sendiri. ${ }^{6}$ Meskipun selama kurun 2014, tidak dipungkiri terdapat applausemasyarakat dan media massa yang memunculkan sentimen positif cukup signifikan tentang kinerja Polri terkait dengan keberhasilannya mengamankan rangkaian proses Pemilu 2014, namun di sisi

\footnotetext{
${ }^{3}$ Kunarto, Merenungi Kritik Terhadap Polri, Jakarta: Cipta Tunggal, 1995, hal.106.

${ }^{4}$ Ibid, hal 108.

5 http://www.bbc.com/indonesia/berita_indonesia/2015/04/150417_kapolri_ haiti_dilantik. Lihat juga http://nasional.kompas.com/read/2015/04/17/ 09274001/ Dilantik.Jokowi. Badrodin.Haiti.Resmi.Jadi.Kapolri.

${ }^{6}$ Analisis data dari database internal Kompolnas (2014-2015).
} 
lain masih terdapat pemberitaan yang berpotensi menimbulkan sentimen negatif yang antara lain terkait pada fungsi-fungsi penanganan kasus kejahatan, pelayanan surat-surat kendaraan bermotor, penanganan kasus narkoba, bentrokan TNI-Polri, penanganan demonstrasi, dan lain-lain. Meskipun banyak dari kasus tersebut terjadi pada level wilayah Polda, namun hal tersebut tetap menyumbang menurunnya tingkat pencitraanpositif yang cukup signifikan tentang kinerja Polri secara keseluruhan.

Pengertian kinerja dari sintesis pendapat beberapa ahli dapat dirumuskan bahwa kinerja adalah pencatatan hasil yang diperoleh dari fungsi-fungsi pekerjaan (functional works) atau kegiatan tertentu selama kurung waktu tertentu dalam mencapai tujuan organisasi. Jadi membahas tentang kinerja Polri akan mengarah kepada hasil atas fungsi pekerjaan atau kegiatan dalam periode yang tertentukan. Artikel pendek ini ditujukan untuk membahas secara ringkas tentang kinerja Polri selaku alat utama negara yang berfungsi sebagai aparat ketertiban dalam masyarakat. Sumber data utama yang diambil adalah pemberitaan di beberapa media massa utama (cetak, elektronik, dan internet) dalam kurun waktu antara awal 2014 sampai dan dwiwulan awal 2015.

\section{Pembahasan}

\section{Kinerja Polri dalam Bingkai Media Massa}

Dalam pantauan penulis selaku anggota komisioner Kompolnas terhadap beberapa media massa, baik media cetak, elektronik, maupun news onlineterutama pertengahan 2014, secara umum lembaga Polri mendapatkan poin positif penting dalam rangka momen pengamanan proses Pemilu karena bisa dikatakan mampu menyukseskannya hingga selesai. Rangkaian proses Pemilu yang terbagi dalam dua tahap yaitu: Pemilu pertama Pemilihan Anggota Legislatif dan Pemilu kedua Pemilihan Presiden menjadi tugas besar dan penting bagi Polri karena merupakan agenda berskala nasional dan memakan rentang waktu relatif panjang sebagai sebuah kegiatan. Polri sebagai penanggung jawab utama pengamanan telah melaksanakannya dengan baik sesuai dengan tupoksinya bukan saja pada hari $\mathrm{H}$ pelaksanaan kedua pemilihan tersebut namun termasuk juga pengamanan pada tahap persiapan, pendaftaran, kampanye, sampai mengawalhasilnya hingga ditetapkan pemenangnya. Agenda pengamanan kegiatan Pemilu tersebut menghabiskan rentang waktu tak kurang dari 7 (tujuh) bulan sejak April hingga Oktober 2014. ${ }^{7}$

Namun, mengingat bahwa di luar tugas pengamanan Pemilu tersebut Polri tetap mengemban tugas rutin utama sebagai pelindung, pengayom, dan pelayanmasyarakat, maka masih terdapat beberapa pemberitaan tentang Polri yang berkonotasi negatif terutama setelah proses Pemilu terlaksana di mana terjadi beberapa peristiwa krusial yang melibatkan lembaga Polri secara langsung meskipun hanya terjadi di tingkat wilayah tertentu. Peristiwa krusial terseut adalah terjadinya gesekan antara Polri dengan TNI di beberapa wilayah antara lain Papua, Binjai, Batam, dan Mojokerto yang semuanya terjadi pada medio akhir 2014. Di samping itu, pada rentang waktu yang hampir bersamaan terjadi banyak demonstrasi menentang kenaikan harga bahan bakar minyak yang dilakukan mahasiswa maupun masyarakat di beberapa daerah yang umumnya berakhir ricuh dengan polisi. Berita-berita di media massa tentang kedua kejadian di atas telah menjadikan pencitraan Polri kembali tereduksi. Sentimen negatif pemberitaan tersebut masih ditambah dengan maraknya pemberitaan tentang aksi kriminalitas terutama di media elektronik televisi dan portal berita internet serta berita-berita lain dengan skala kecil tentang keluhan dalam pelayanan SKCK,

\footnotetext{
${ }^{7}$ Data Kompolnas, Ibid.
} 
SIM-STNK Keliling, plat kendaraan bermotor, keluhan aparat yang menjadi beking kegiatan legal/ilegal, terlibat narkoba, dan kasus salah tangkap.

Selanjutnya, sejak kurun awal tahun sampai awal Maret 2015, terjadi eskalasi pemberitaan tentang Polri yang mengarah kepada sentimen negatif yang lebih kuat menusuk tubuh Polri dengan hebohnya pemberitaan mengenai Komjen Budi Gunawan sebagai calon tunggal Kapolri yang tinggal menunggu hari dilantik tapi secara mendadak ditetapkan sebagai tersangka oleh KPK. Berita tersebut bukan saja menjadi hot news di media massa papan atas malah juga menjadi trending topic di berbagai media sosial internet saking sensasionalnya. Inilah awal mula "drama lama" dengan sekuel baru terjadi kembali antara Polri dan KPK. Pemberitaan tentang Polri masih didominasi "Polri versus KPK" dengan dimenangkannya gugatan praperadilan oleh pihak Komjen Budi Gunawan yang secara otomatis menggugurkan status tersangka yang disandangnya. Muncullah berita lanjutan tentang spekulasi baru mengenai peluang Budi Gunawan untuk tetap menjadi Kapolri sementara sebelumnya Presiden telah mengangkat Badrodin Haiti selaku pejabat pelaksana tugas Kapolri. Meskipun demikian akhirnya masalah tersebut dapat diselesaikan pada level tertinggi negara yaitu Presiden sebagai Kepala Pemerintahan yang mempunyai hak prerogatif mengangkat Kapolri baru yaitu Jenderal Polisi Badrodin Haiti.

Di luar peristiwa di atas, pada media awal 2015 pemberitaan tentang Polri yang lain adalah adalah berita-berita bercitra positif maupun negatif tentang peristiwa-peristiwa hukum biasa. Pemberitaan dengan sentimen negatif misalnya Kasus Labora Sitorus di Papua, Aksi 'Koboi’ AKP Hadi di Jawa Tengah, dan Anggota Polri Mengonsumsi Narkoba di Madura.

Adapun yang mengarah pada sentimen positif misalnya Razia Preman di Jakarta, Penggagalan illegal logging di Kaltim, dan pengawalan terhadap para terpidana mati di berbagai lapas. Peristiwa-peristiwa tersebut tersebar dan terjadi di berbagai tempat dan melibatkan Polri pada level Polda di berbagai daerah, namun dapat dikatakan tidak semua Polda mendapat eksposure pemberitaan yang kuat. Untuk pulau Jawa didominasi oleh Polda Metro Jaya dan Polda Jawa Timur sedangkan di luar pulai Jawa bisa dikatakan tidak ada Polda yang dominan dalam eksposure pemberitaan. ${ }^{8}$

Dalam kaitan dengan media, kasus lain di masa lalu adalah, ketika polisi memanggil wartawan. Kali ini dalam kasus pencemaran nama baik Nazaruddin terhadap Anas Urbaningrum. Kepolisian RI nampaknya tak mau belajar dari sejarah.

Polri harus hati-hati sebab pers adalah pilar keempat dalam demokrasi, dimana jika eksekutif, legislatif dan yudikatif berselingkuh atau menyeleweng, maka kontrol pers sangat krusial untuk membawa demokrasi ke jalan yang benar atau rasional. Pers bukan sekadar anjing penjaga, melainkan bisa pula berfungsi sebagai sang pencerah.

Dalam kasus pemanggilan wartawan grup Tempo oleh polisi, hal itu menunjukkan ada kealpaan atau amnesia di tubuh polisi sendiri. Lantas, siapa pejabat Polri yang keliru bertindak dalam konteks ini? Ini jelas soal kredibilitas dan kapasitas sang pejabat polisi itu sendiri. Artinya, institusi Polri harus jeli, cermat dan korektif serta introspektif.

Polri mengakui telah memanggil dua orang wartawan dari harian Tempo, untuk diperiksa sebagai saksi kasus dugaan pencemaran nama baik Ketua Umum Partai Demokrat Anas Urbaningrum. "Memang dari penyidik ada memanggil beberapa saksi di antaranya dari wartawan," kata Kepala Divisi Hubungan Masyarakat Polri Inspektur Jenderal Anton Bachrul Alam, Kamis (25/8/2011).

Namun kedua wartawan ini dikabarkan tidak memenuhi panggilan polisi, sehingga belum ada konfirmasi lebih lanjut. "Jadi belum bisa dilakukan pemeriksaan belum bisa

\footnotetext{
8 Lihat liputan-liputan berita-berita tersebut antara lain di kompas.com, detik.com, inilah.com dan kaltim.antaranews.com.
} 
dilakukan," kata Anton. Pemeriksaan terkait kasus pencemaran nama baik yang dilakukan oleh mantan Bendahara Umum Partai Demokrat M Nazaruddin.

Aliansi Jurnalis Independen (AJI) menyesalkan sikap Polri yang melakukan pemanggilan atas tiga wartawan Koran Tempo terkait laporan Ketum Partai Demokrat (PD) Anas Urbaningrum untuk kasus Nazaruddin. Padahal polisi bisa mencari bukti lain tanpa melakukan pemanggilan pada wartawan.

Polri harus paham dan selalu ingat bahwa sesuai UU Pers, wartawan punya hak untuk menolak pemanggilan. Ketua Dewan Pers Bagir Manan menegaskan bahwa wartawan berhak menolak memberikan keterangan kepada pihak kepolisian apabila terkait isi pemberitaan. Sepenuhnya isi berita sudah menjadi tanggung jawab redaksi. Karena soal isi berita tanggung jawab redaksi, kata Bagir Manan belum lama ini. Bagir menjelaskan, wartawan saat dipanggil pun harus jelas statusnya apa. Pemeriksaan seharusnya dilakukan kemarin,. Tiga wartawan Koran Tempo itu dalam surat pemanggilan menjadi saksi terkait kasus dugaan pencemaran nama baik yang dilaporkan Anas Urbaningrum atas Nazaruddin. Salah satu yang dipanggil adalah redaktur Koran Tempo Sukma N Lopies. Sudah tepat bahwa Tempo memilih tidak datang. AJI khawatir pemanggilan ini nantinya menjadi preseden, di mana setiap laporan pencemaran nama baik polisi memanggil wartawan. Seharusnya polisi bisa mencari alat bukti lain. Pada Selasa 5 Juli Anas Urbaningrum melaporkan mantan bendahara umum PD Nazaruddin ke Mabes Polri. Nazaruddin melalui pesan BlackBerry Messenger (BBM) dinilai telah menyebarkan fitnah terkait Anas. Nazaruddin dituding mencemarkan nama baik Anas setelah dikaitkan dengan kasus Wisma Atlet.

Media juga kian banyak memberitakan aknum polisi yang bunuh diri. Maraknya kasus kekerasan bersenjata api yang dilakukan oleh aparat kepolisian menunjukkan lemahnya sistem perekrutan di lembaga tersebut. Oleh sebab itu, sistem perekrutan kepolisian harus diperbaiki. Terutama dalam hal tes psikotes harus dibedakan dengan tes psikotes untuk penerimaan PNS atau yang lain karena mereka itu tanggung jawabnya besar. Ingat bahwa ada polisi yang tega menembak istrinya karena bertengkar atau putus cinta dengan kekasihnya lalu bunuh diri. Belakangan ini ada beberapa peristiwa memilukan terkait penguasaan senjata api oleh personel Kepolisian Indonesia dan TNI AD. Seorang bintara tinggi Kepolisian Indonesia bunuh diri dengan menembak kepalanya, dan seorang bintara Kostrad TNI AD menembak mati di tempat seorang warga sipil.

Berbagai kalangan menyatakan prihatin melihat maraknya fenomena kasus polisi bunuh diri. Apalagi kasus bunuh diri banyak terjadi di Jakarta atau di lingkungan Polda Metro Jaya. Sepanjang 10 bulan di 2015, sudah terjadi enam kasus polisi bunuh diri, dua di antaranya bunuh diri di rumah pacarnya di Jakarta.

Kasus terakhir adalah kasus bunuh diri dilakukan Kanit Lantas POlsek Cipondoh Iptu Budi Riyono di rumah wanita idaman lain-nya H di Perumahan. Griya Kenangan, Cipondoh, Tangerang, Banten pada 31 Oktober 2015. Kasus tersebut menunjukkan, sebagai seorang perwira Polri yang bersangkutan tidak mampu mengontrol emosinya, sehingga mengambil jalan pintas.

Adanya lubang bekas tembakan di kepala kanan di atas daun telinga korban, sementara tangan kanannya memegang pistol revolver kaliber $38 \mathrm{~mm}$ menunjukkan betapa gampangnya yang bersangkutan frustrasi, sehingga nekat mengambil jalan pintas menghabisi hidupnya sendiri.

Kasus polisi bunuh diri dari waktu ke waktu menunjukkan tren peningkatan. Dalam lima bulan pertama 2015 ada tiga polisi bunuh diri. Pada 2014 juga ada tiga polisi bunuh diri. Salah satunya adalah Brigadir Satu Polisi Guntur, anggota Satuan Reserse Kriminal Polres Sukabumi Kota, Jawa Barat, yang ditemukan tewas di kontrakannya di Jalan Taman Bahagia, Kota Sukabumi. 
Ia bunuh diri dengan senjata apinya pada 22 Januari 2014, setelah cekcok dengan pacarnya yang bernisial WI. Jumlah anggota Kepolisian Indonesia yang bunuh diri pada 2013 naik 300 persen lebih, jika dibandingkan tahun-tahun sebelumnya. Pada 2011 hanya ada satu polisi yang bunuh diri di Sumatera Utara. Pada 2011 naik menjadi dua orang, dan tahun 2013 ada tujuh polisi yang bunuh diri. Lima polisi jajaran bawah dan dua perwira polisi. Sebagian besar gantung diri di rumahnya.

Menurut data IPW, hal yang paling mengejutkan adalah penyebab kejadiannya berlatar belakang persoalan pribadi. Dalam lima bulan pertama pada 2015 misalnya, ada tiga polisi bunuh diri. Terakhir Brigadir Wahyudi menembak kepalanya sendiri di rumah kekasihnya di Kalideres, Jakarta Barat pada 16 Mei 2015, setelah bertengkar dengan pacarnya.

Sebagai langkah antisipatif, Kepolisian Indonesia perlu mengetatkan pemakaian senjata api dan kembali melakukan serangkaian tes bagi anggotanya. Hal tersebut perlu untuk mengecek kembali kondisi mental anggota Polri ketika mereka memiliki senjata api. Langkah lainnya adalah Polri harus membenahi pola perekrutan anggota sejak awal. Proses seleksi rekrutmen masuk anggota kepolisian harus benar-benar profesional.

\section{Kesimpulan}

Simpulan dari uraian di atas adalah bahwa walau selama 2014 Polri berperan besar dalam mengamankan rangkaian proses Pemilu, tetapi eksposure pemberitaan media masih banyak yang memuat sentimen negatif tentang kinerja Polri yang lain sehingga mempengaruhi anggapan dan sikap masyarakat terhadap Polri. Selanjutnya selama triwulan 2015, Polri tampaknya belum mau/ mampu secara signifikan melakukan langkah-langkah kepedulian guna menekan sentimen negatif tersebut sekaligus meningkatkan sentimen positif.

Uraian di atas mengambarkan secara garis besar potret Polri di beberapa media massa utama nasional, baik media cetak, elektronik, maupun situs berita internet yang menjadi obyek pengamatan penulis diantaranya Kompas, Koran Tempo, MetroTV, TVOne, detik, dan liputan6.Diperlukan telaah lebih dalam untuk mendapatkan hasil analisis yang lebih lengkap yang tentunya tidak mungkin semua diuraikan dalam tulisan ini.

\section{Daftar Pustaka}

Satjipto Raharjo dan Anton Tabah. Polisi, Pelaku dan Pemikir, Jakarta: Gramedia Pustaka Utama, 1993.

Kunarto, Merenungi Kritik Terhadap Polri, Jakarta: Cipta Tunggal, 1995. Adrianus Meliala, Memulai Lagi Reformasi Kepolisian, Kompas, 23 Juni 2015 Database internal Kompolnas (2014-2015).

bbc.com

nasional.kompas.com detik.com

inilah.com kaltim.antaranews.com. 